\title{
Fabrício Carpinejar
}

Como você pensa a relação entre o tempo literário e o tempo histórico?

Tenho a sincera percepção de que sou adubo, pasto para gerações futuras. Tentarei fazer meu melhor - o máximo que puder - para que novos poetas venham e tenham a capacidade de produzir a síntese de nosso tempo. Para gerar um clássico, alguém tem que segurar a escada. Fico ali embaixo, com as duas mãos e o sentimento do meu pátio.

\section{Quais procedimentos sua obra adota diante de um mundo em que predominam a ação econô- mica e a espetacularização da arte?}

$O$ poema tem a velocidade de um desaforo, permite utilizar a rapidez a seu favor, procurando ampliar espaços de intensidade e densidade e articular pontos de dispersão e incoerência. É capaz de usar a própria espetacularização como arrancada para a inversão de pontos de vista e questionar as fragilidades dos condicionamentos. Não há erva venenosa - que destilada não cure alguma coisa.

\section{Qual reflexão sua obra produz sobre a tradição literária brasileira?}

Acredito que seja a família. Toda a minha obra poética gira no mesmo tema obsessivo: a relação familiar com o mundo e o mundo secreto em que a família filtra as relações sociais. Não mudo meu foco, giro meu ponto de vista. Desloco a minha posição de olhar. Minha obra é uma verdadeira dança das cadeiras. Já fui o filho, a mãe, o irmão, o pai, o avô, o neto, a mulher. Cada livro é uma identidade exposta e fraturada de uma versão.
A poesia brasileira tem a responsabilidade de questionar, de procurar compreender os costumes e suas lacunas. Nenhum assunto está devidamente esgotado, a literatura desarquiva os demônios para aumentar a claridade. Meu filho, minha filha segue o fio da pandorga da família. Discute esse novo modelo de família, em que os filhos têm duas casas, os pais ainda estão confusos entre a democracia e a falta de limites e os padrastos e madrastas procuram a autenticidade de sua inserção na educação dos enteados. Perguntar é se comover. Responder é não sair do lugar. Poesia pergunta sobre pergunta. $\mathrm{O}$ amor somente cresce na dúvida.

\section{Como você pensa a forma literária?}

Eu sou a minha respiração. Nem sempre grito. Suspiro, sussurro, gemo. Cada poesia é uma nuance do sopro. $O$ poeta é aquele que não sai da adolescência e vive mudando a voz - para não perder o impacto de dizer.

Fabrício Carpinejar (1972) é autor dos livros de poesia As solas do sol (Bertrand Brasil, 1998), Terceira sede (Escrituras, 2001), Biografia de uma árvore (Escrituras, 2002), Caixa de sapatos (Companhia das Letras, 2003), Cinco Marias (Bertrand Brasil, 2004), Como no céu e Livro de visitas (Bertrand Brasil, 2005), Meu filho, minha filha (Bertrand Brasil, 2007), Um terno de pássaros ao sul (Bertrand Brasil, 2008), Canalha! (Bertrand Brasil, 2008); e do livro de crônica O amor esquece de começar (Bertrand Brasil, 2006), e outros. 